\title{
TRUST ON VIRAL ADVERTISING MESSAGES AND ITS IMPACT ON CONSUMERS ATTITUDE
}

\author{
S. R. Arun \\ Ph.D. Research Scholar, Department of Business Administration, Annamalai University, \\ Annamalainagar - 608002 \\ and \\ Dr. M. Arul \\ Professor, Department of Business Administration, Annamalai University, \\ Annamalainagar - 608002
}

\begin{abstract}
The purpose of this paper is to contribute to the growing body of research on viral advertising messages which is based on viral marketing, while concentrating on trust of viral advertising messages and its effect on consumer attitude. The population of this study is who purchased products through viral advertising in Chennai city, the sample is 635 respondents. In order to measure the variables used in this research, a questionnaire was used. Also, Statistical methods were used for the analysis of final descriptive and inferential statistics. The findings showed that there is a significant relationship between the trust on viral message and consumer attitude.
\end{abstract}

Keywords: Trust, Viral Advertising, Viral messages, Consumer, Attitude

\section{Introduction}

Integrating marketing and IT principles suggests new and advanced models of the marketing world such as viral marketing (Aghdaie, et al, 2012) consumption, and often includes international consumers. It's easy to pinpoint an infected message because they naturally circulate among people with common behaviors or interests where viral marketing exploits existing social networks by encouraging customers to share product information with their friends. This approach is important for both consumers and companies. Consumers get the things they want, such as discounts, free products, or important information and companies get the benefits.

Therefore, viral marketing (VM) assumes that as each new user begins to use an app or product, advertising will go to everyone that user. Using the Internet is a virtual reality (VM) manager, administrators (or personal computer users) are the ones who do the hard work of virus creators, spreading the virus via email and other social media at the click of a button. The recipient (new manager) can effectively spread the virus if that virus is considered appropriate in their eyes, greatly enhancing the distribution and effectiveness of the campaign.

Typically, viral marketing involves the distribution of a marketing message through the voice of a mouse to ensure that recipients are interested in passing the message on to their friends. In addition, (VM) reflects the characteristics of current marketing trends including customized marketing, affiliate marketing, relationship marketing and impact marketing (Yang, 2012). 